\title{
Genetic Variability and Correlation Coefficient for Fodder Yield and its Components in Forage Pearl Millet Hybrids under Rainfed Conditions of Gujarat
}

\author{
K. K. Dhedhi ${ }^{1 *}$, V. V. Ansodariya ${ }^{2}$, N. N. Chaudhari $^{1}$, J. M. Sanghani ${ }^{1}$ and J. S. Sorathiya ${ }^{1}$
}

${ }^{1}$ Pearl millet Research Station, Junagadh Agricultural University, Jamnagar, Gujarat (361 006), India

${ }^{2}$ Grassland Research Station, Junagadh Agricultural University, Dhari Amreli, Gujarat (365 640), India

\section{Article History}

Manuscript No. AR1645

Received in $28^{\text {th }}$ July, 2016

Received in revised form $22^{\text {nd }}$ September, 2016

Accepted in final form $24^{\text {th }}$ September, 2016

\section{Correspondence to}

*E-mail:kkdhedhi@rediffmail.com

\section{Keywords}

Forage pearl millet, variability, heritability, correlation coefficient

\begin{abstract}
The 29 forage pearl millet hybrids were studied for genetic variability, heritability, genetic advance and character association of green fodder yield and its components at Jamnagar and Dhari centers of Junagadh Agricultural University, Gujarat under rainfed conditions during kharif, 2014. The analysis of variance revealed highly significant differences among the hybrids for all the characters studied except lodging score and harvest index. Wide range of phenotypic variability was observed for green fodder yield plant ${ }^{-1}$, dry fodder yield plant ${ }^{-1}$ and plant height, indicating the scope for genetic improvement through selection and other breeding methods. PCV and GCV estimates were found to be high to moderate for harvest index $(33.49 \%, 25.68 \%)$, lodging score $(34.16 \%, 20.77 \%)$, grain yield plant ${ }^{-1}(29.63 \%, 20.96 \%)$, dry fodder yield plant ${ }^{-1}$ $(26.49 \%, 20.42 \%)$ and green fodder yield plant ${ }^{-1}(23.44 \%, 16.45 \%)$ which suggests that there is enough scope for selection. Broad sense heritability ranged from $37.00 \%$ (lodging score) to $81.60 \%$ (plant height). The high heritability coupled with high to moderate genetic advance expressed as percentage of mean was observed for plant height $(81.60 \%, 23.84 \%)$, harvest index $(58.80 \%, 40.58 \%)$, dry fodder yield plant ${ }^{-1}$ $(59.40 \%, 32.43 \%)$ and grain yield plant ${ }^{-1}(50.10 \%, 30.55 \%)$ which showed that these traits were controlled by additive gene effects and phenotypic selection were for these traits were likely to be effective. Correlation analysis revealed that green fodder yield plant $^{-1}$ had significant positive association with dry fodder yield plant ${ }^{-1}(0.962,0.926)$ and days to maturity $(0.483,0.395)$ at both genotypic and phenotypic levels, and days to $50 \%$ flowering (0.612) and plant height (0.490) at genotypic level only. Hence, these characters would be more effective for boosting green fodder yield performance of forage pearl millet hybrids.
\end{abstract}

\section{Introduction}

Pearl millet [Pennisetum glaucum (L.) R. Br.] is a major warm season cereal crop of rainfed region. It is not only important as a grain crop, but is an indispensable source of dry fodder in dry tracts of South-Western Haryana, Gujarat and Rajasthan. Being a $\mathrm{C}_{4}$ species, it has tremendous potential for biomass production, most of which is accumulated in its vegetative parts. The green fodder of pearl millet is leafy, palatable and very nutritious feed stock for cattle ensuring good milk yield. Being any time forage, pearl millet, unlike sorghum, can be grazed, or cut and fed at any growth stage, as it has no HCN content. Pearl millet is excellent for producing silage, particularly in regions with dry spells during the rainy season (Shashikala et al., 2013). The production potential of green fodder of pearl millet at present is however, low. Obviously if productivity of the animal population has to be improved, high fodder yielding varieties of pearl millet need to be developed. Progress in any crop improvement venture depends mainly on the magnitude of genetic variability and heritability present in the source material. The extent of variability is measured by GCV and PCV which provides information about relative amount of variation in different characters. Hence, to have a thorough comprehensive idea it is necessary to have an analytical assessment of yield components. Since heritability is also influenced by environment, the information on heritability alone may not help in pin pointing characters enforcing selection. Nevertheless, the heritability estimates in conjunction with the predicted genetic advance will be more reliable (Johnson et al., 1955). Heritability gives the information on the magnitude of inheritance of quantitative traits while genetic advance will be helpful in formulating 
suitable selection procedures. High heritability coupled with high genetic advance values were reported in pearl millet by Vidyadhar et al. (2007) for days to flowering and days to maturity; Lakshmana et al. (2009) for plant height, productive tillers plant ${ }^{-1}$ and grain yield plant ${ }^{-1}$; Singh et al. (2014a) for plant height, biological yield plant ${ }^{-1}$, dry fodder yield plant ${ }^{-1}$ and grain yield plant ${ }^{-1}$; and Dhedhi et al. (2016) for harvest index, grain yield plant ${ }^{-1}$, dry fodder yield plant ${ }^{-1}$, days to $50 \%$ flowering and plant height suggesting selection for these traits would give good responses. Knowledge of the presence of association among the supplementary characters assumes a unique prominence as the basis for selecting desirable genotypes with high fodder yield potential. Bhagirath Ram et al. (2007) reported that green fodder yield plot $^{-1}$ showed high positive correlation with tillers plant ${ }^{-1}$, dry fodder yield plant $^{-1}$, green fodder yield plant ${ }^{-1}$ and plant height. Singh et al. (2014a) mentioned that grain yield plant ${ }^{-1}$ had significant positive correlation with plant height, biological yield plant ${ }^{-1}$, dry fodder yield plant ${ }^{-1}$ and harvest index. Dhedhi et al. (2015) reported that green fodder yield plant ${ }^{-1}$ had significant positive association with days to $50 \%$ flowering, days to maturity and dry fodder yield plant ${ }^{-1}$ at both genotypic and phenotypic levels. Dhedhi et al. (2016) in their study mentioned the dry fodder yield plant ${ }^{-1}$, plant height, days to $50 \%$ flowering had positive correlation with green fodder yield plant ${ }^{-1}$. Therefore, the present investigation was undertaken to study the genetic variability, heritability and character association for green fodder yield and its components in forage pearl millet hybrids during rainy season of 2014 at Jamnagar and Dhari centre.

\section{Materials and Methods}

Two seed set of 29 forage hybrids of pearl millet (Table 1) including six checks viz., ICMV 05555, ICMV 08111, DFMH 70, DFMH 88, DFMH 30 and PAC 981 were supplied by ICRISAT, Patancheru, Hyderabad. Field experiments were conducted at Pearl millet Research Station, Junagadh Agricultural University (JAU), Jamnagar and Grassland Research Station, JAU, Dhari, during rainy season of 2014. The design of the trail was randomization complete block design with two replications at both the locations. Each plot consisted of four rows of $4.0 \mathrm{~m}$ long and $60 \mathrm{~cm}$ apart in both locations. Middle two rows were considered for all the observations. Thus, the net plot size was $4.0 \times 1.20 \mathrm{~m}^{2}$. The trial was planted on $24^{\text {th }}$ July, 2014 and $25^{\text {th }}$ July, 2014 at Jamnagar and Dhari centre, respectively. While, the trial was harvested on $30^{\text {th }}$ October, 2014 and $10^{\text {th }}$ November, 2014 at Jamnagar and Dhari centre, respectively. The crop was supplied with recommended dose of fertilizer $80-40-00 \mathrm{NPK} \mathrm{kg} \mathrm{ha-1}$ at both locations. Observations on days to $50 \%$ flowering, days to maturity, plant height $(\mathrm{cm})$, plant population plot ${ }^{-1}$, grain yield $\left(\mathrm{kg} \mathrm{plot}^{-1}\right)$, dry stalk yield (dry fodder yield, $\mathrm{kg} \mathrm{plot}^{-1}$ ), fresh stalk yield (green fodder yield, $\mathrm{kg} \mathrm{plot}^{-1}$ ) and lodging score (1-5) were recorded.
Days to $50 \%$ flowering, days to maturity and lodging score (1-5) was recorded on plot basis. The plant height in centimeter was recorded from the base of the plant to the tip of the panicle at harvesting stage. Five randomly selected plants from each plot were used to record the plant height. The data of grain yield $\left(\mathrm{kg} \mathrm{plot}^{-1}\right)$, dry fodder yield $\left(\mathrm{kg} \mathrm{plot}^{-1}\right)$ and green fodder yield $\left(\mathrm{kg} \mathrm{plot}^{-1}\right)$ from net plot were recorded and computed as in gram plant ${ }^{-1}$. Mean values were subjected to standard statistical procedures namely, analysis of variance (Panse and Sukhatme, 1978), phenotypic and genotypic variances (Lush, 1940) genotypic and phenotypic co-efficient of variations (Burton, 1952) and heritability and genetic advance (Johnson et al., 1955). Phenotypic and genotypic correlation coefficients were computed utilizing the procedure described by Falconer (1964). The significance of correlation coefficient was tested by referring to the standard table given by Snedecor (1961).

\section{Results and Discussion}

Analysis of variance (Table 2) revealed significant variation for all the characters under study except lodging score and harvest index in individual location and pooled over locations indicating considerable amount of genetic variation present in the materials and ample scope of improvement by selection. Mean of different parameters of forage pearl millet hybrids at individual and pooled over locations are presented in Table 1. The range of variation and the estimates of genetic parameters like heritability in broad sense, coefficient of variation (PCV and GCV) and genetic advance expressed as percentage of mean in individual location and pooled over locations are presented in Table 2. While, genotypic and phenotypic correlation coefficients among traits pooled over locations are presented in Table 3 . The results are discussed only on pooled basis as under.

The perusal of Table 1 revealed that hybrid ICMA $10999 \times$ HHVBC tal was the earliest flowered (48 days), while check PAC 981 was the latest flowered (66 days) amongst all the hybrids. Days to maturity ranged from 73 days (ICMA $10999 \times$ HHVBC tal) to 92 days (check PAC 981). Plant height ranged from $181 \mathrm{~cm}$ (ICMA $07999 \times$ HHVBC tal) to $308 \mathrm{~cm}$ (check DFMH 70). Lodging score varied from 1.00 to 1.50 over the locations. The cross ICMA 00999 $\times$ IP 6202 produced the maximum green fodder yield plant ${ }^{-1}(299 \mathrm{~g})$ among all the crosses followed by ICMA $01888 \times$ ICMV $05222(277 \mathrm{~g})$ and ICMA 09888×IP $22269(246 \mathrm{~g})$. The cross ICMA 00999×IP 6202 produced the highest dry fodder yield plant ${ }^{-1}(158 \mathrm{~g})$ among all the crosses followed by ICMA $01888 \times$ ICMV 05222 (143 g) and ICMA 09888×IP 22269 (126 g). It is interesting to note that the tall crosses were, in general, produced high green as well as dry fodder yield plant ${ }^{-1}$. The check DFMH $88(27.10 \mathrm{~g})$ ranked top in grain yield plant ${ }^{-1}$ among all the hybrids followed by check DFMH $70(23.44 \mathrm{~g})$ and cross ICMA 01888×IP 6140 (21.01 g). Checks ICMV 05555 and 


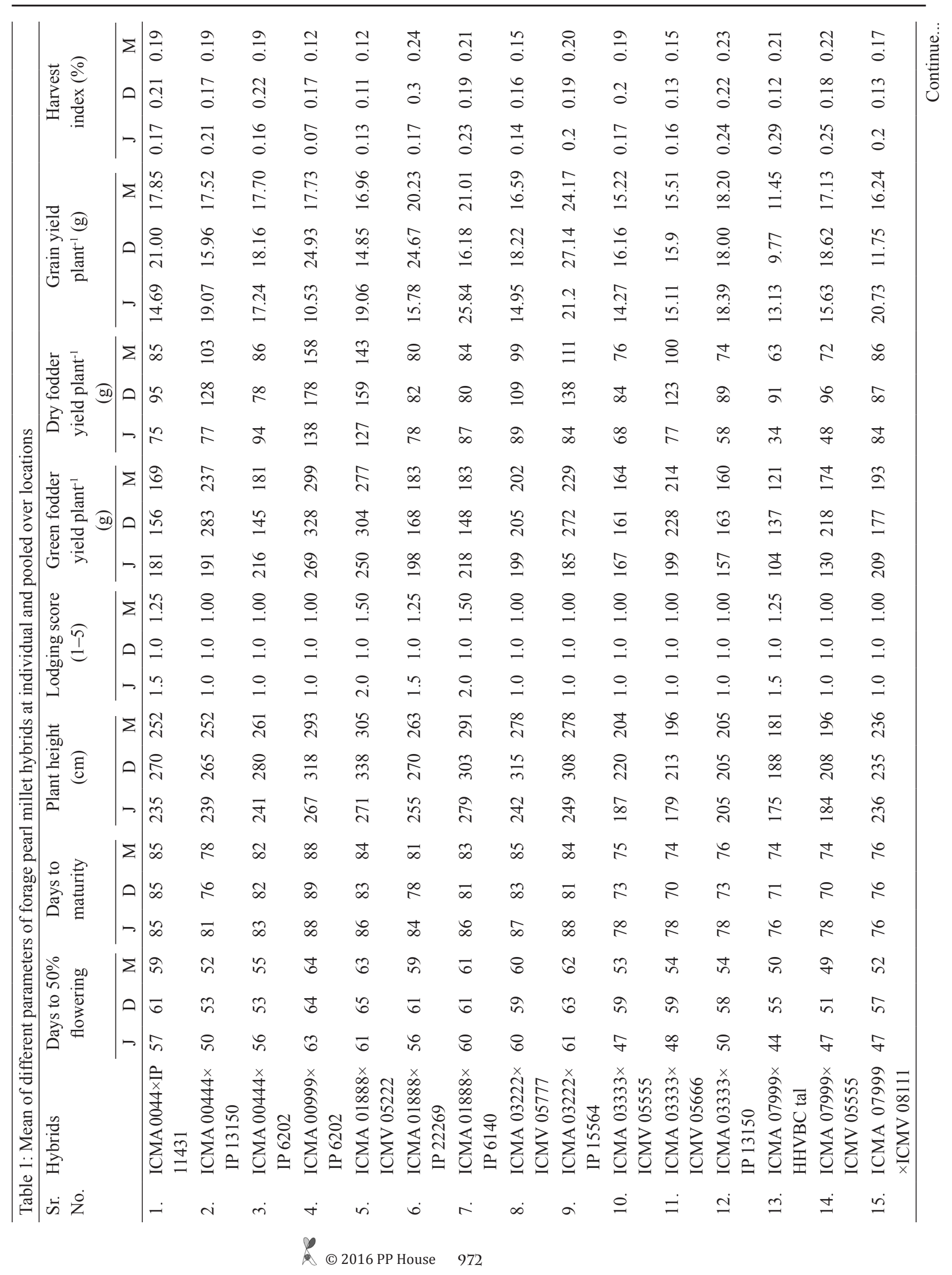




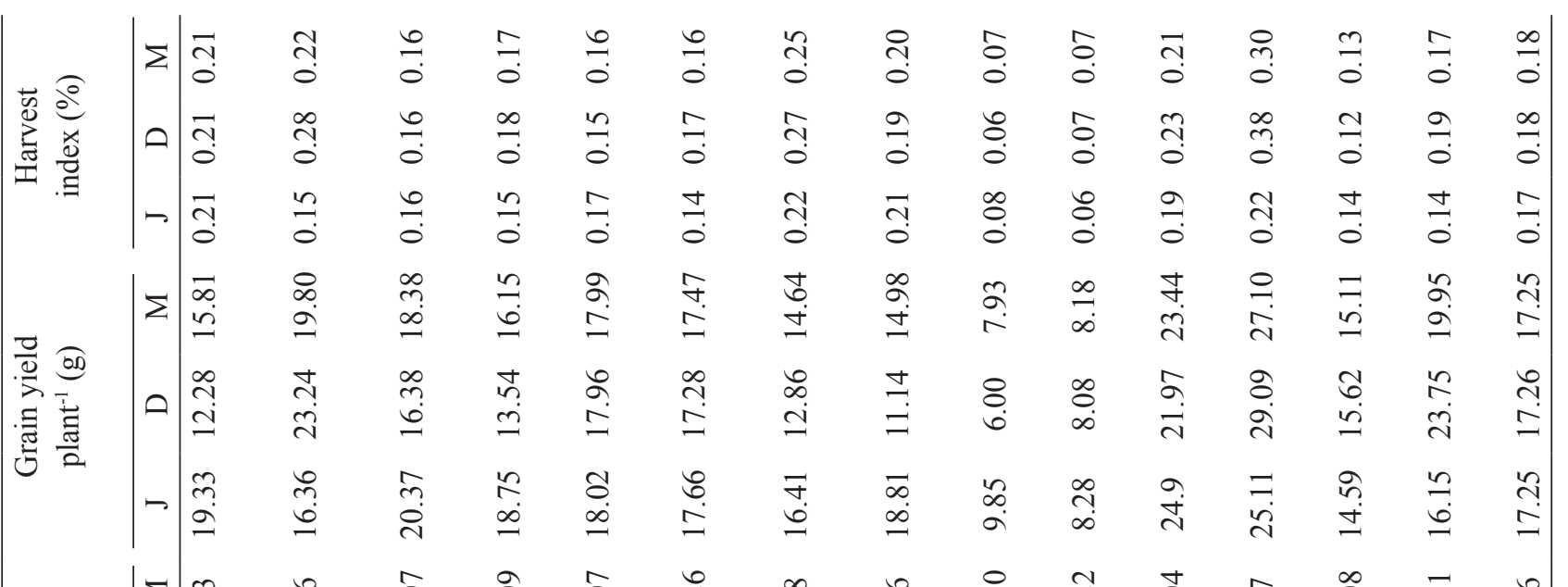

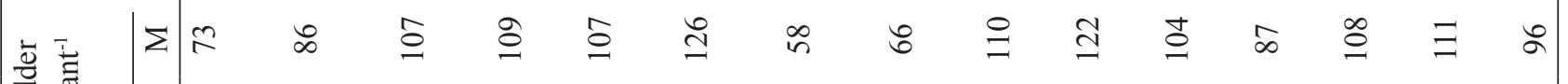

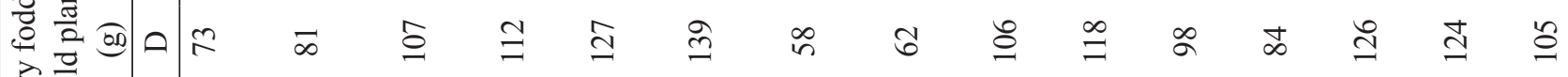

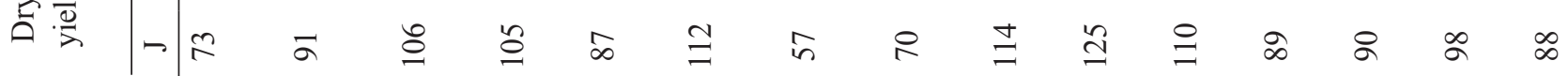

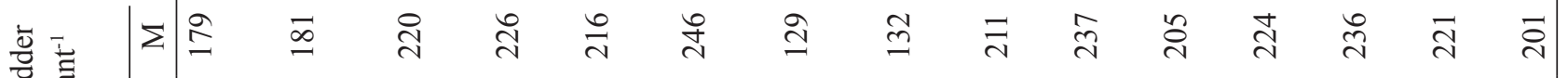

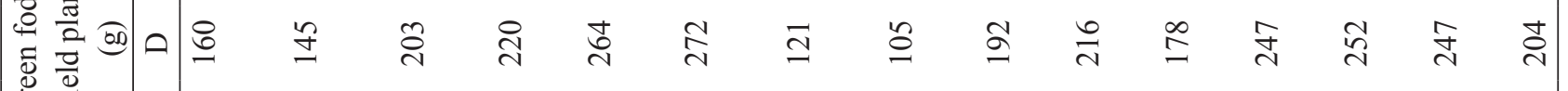
ปे

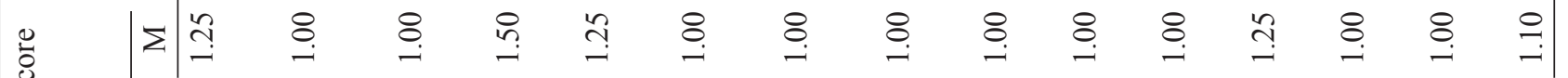

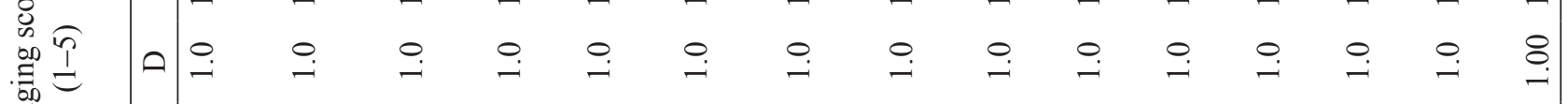

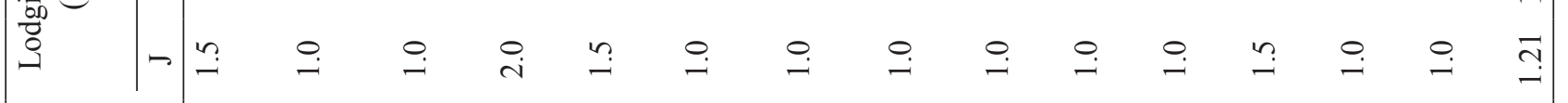

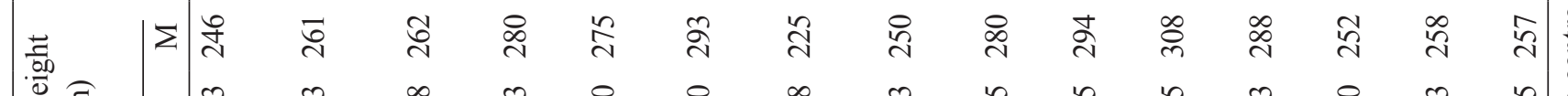

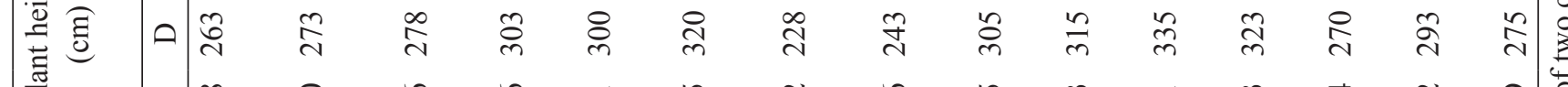

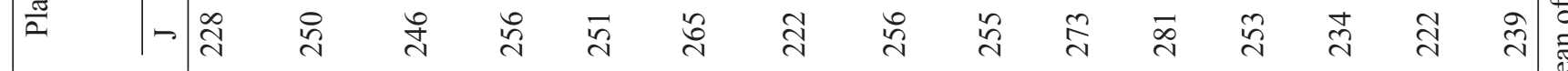

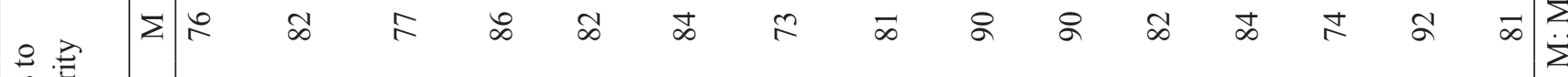
氙䔍

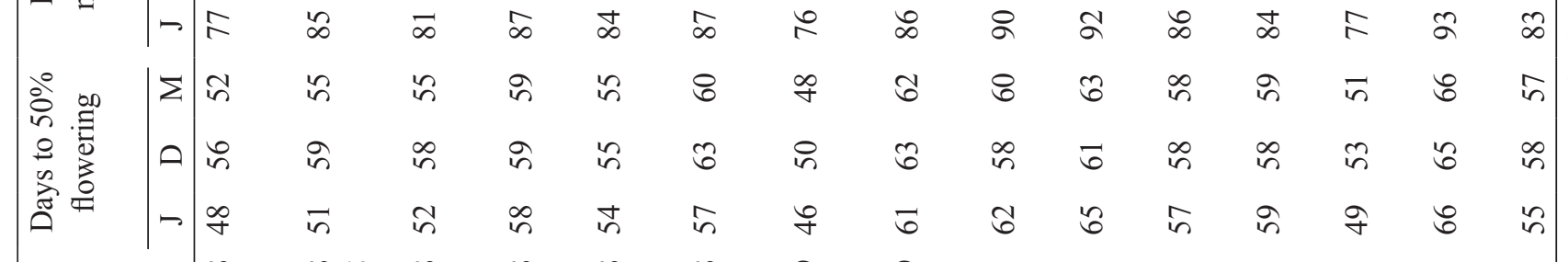

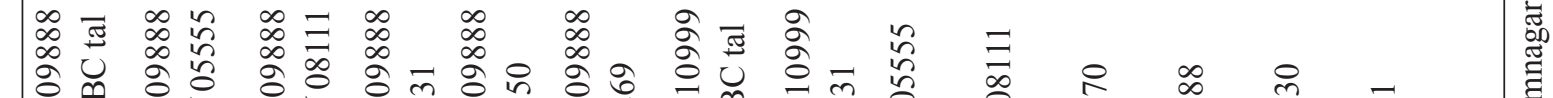

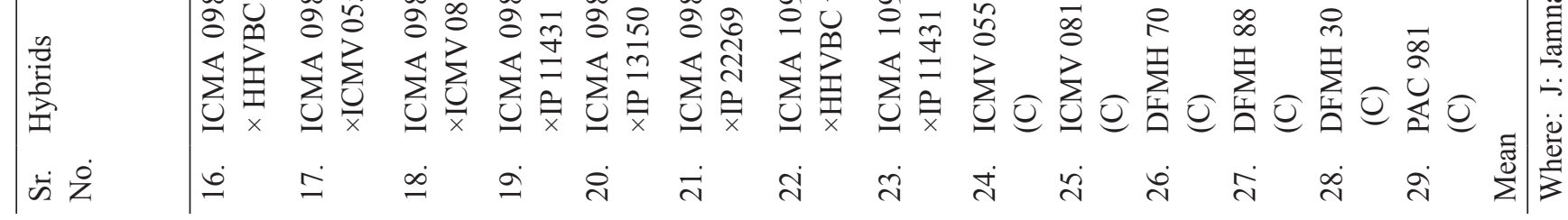


Table 2: Analysis of variance showing mean squares, and variability parameters for different traits in individual location and pooled over locations in forage pearl millet hybrids

\begin{tabular}{|c|c|c|c|c|c|c|c|c|c|}
\hline \multicolumn{2}{|c|}{ Parameter } & DF & $\mathrm{DM}$ & $\mathrm{PH}(\mathrm{cm})$ & LS (1-5) & GFYP (g) & $\operatorname{DFYP}(\mathrm{g})$ & GYP $(\mathrm{g})$ & HI (\%) \\
\hline \multicolumn{10}{|c|}{ Jamnagar $\left(\mathrm{E}_{1}\right)$} \\
\hline \multirow{3}{*}{$\begin{array}{l}\text { Mean } \\
\text { sum of } \\
\text { squares }\end{array}$} & Replications (1 df) & 0.28 & 0.19 & $86.8^{* *}$ & 0.001 & $9569^{* *}$ & $1689^{* *}$ & 0.71 & 0.02 \\
\hline & Hybrids (28 df) & $81.8^{* *}$ & $48.8^{* *}$ & $1724^{* *}$ & 0.23 & $4690^{* *}$ & $1273^{* *}$ & $60.9^{* *}$ & 0.01 \\
\hline & Error $(28 \mathrm{df})$ & 1.42 & 1.69 & 176 & 0.11 & 1158 & 219 & 10.7 & 0.002 \\
\hline \multicolumn{2}{|l|}{ Mean } & 55 & 83 & 239 & 1.21 & 199 & 88 & 17.5 & 0.17 \\
\hline \multicolumn{2}{|l|}{ Range } & $44-66$ & $76-93$ & $175-281$ & $1-2$ & $104-269$ & $34-138$ & $8.28-25.84$ & $0.06-0.29$ \\
\hline \multicolumn{2}{|c|}{ Phenotypic variance } & 41.61 & 25.25 & 950 & 0.17 & 2924 & 746 & 35.78 & 0.007 \\
\hline \multicolumn{2}{|c|}{ Genotypic variance } & 40.19 & 23.56 & 774 & 0.06 & 1766 & 527 & 25.09 & 0.005 \\
\hline \multicolumn{2}{|c|}{ Environment variance } & 1.41 & 1.69 & 176 & 0.11 & 1158 & 219 & 10.69 & 0.002 \\
\hline \multicolumn{2}{|l|}{ PCV \% } & 11.82 & 6.05 & 12.89 & 34.16 & 23.74 & 27.47 & 30.21 & 39.33 \\
\hline \multicolumn{2}{|l|}{ GCV \% } & 11.62 & 5.84 & 11.64 & 20.77 & 18.45 & 23.10 & 23.30 & 32.22 \\
\hline \multicolumn{2}{|c|}{ Heritability \% } & 96.60 & 93.30 & 81.50 & 37.00 & 60.4 & 70.70 & 70.10 & 67.10 \\
\hline \multicolumn{2}{|c|}{ GA (\% mean) } & 23.53 & 11.62 & 21.64 & 26.01 & 29.54 & 39.99 & 43.64 & 54.37 \\
\hline \multicolumn{10}{|c|}{ Dhari $\left(\mathrm{E}_{2}\right)$} \\
\hline \multirow{3}{*}{$\begin{array}{l}\text { Mean } \\
\text { sum of } \\
\text { squares }\end{array}$} & Replications (1 df) & 0.08 & $6.25^{*}$ & $21.0^{* *}$ & 0.00 & $1410^{* *}$ & $1490^{* *}$ & $1409^{* *}$ & 0.17 \\
\hline & Hybrids ( 28 df) & $32.51^{* *}$ & $76.7^{* *}$ & $3608^{* *}$ & 0.00 & $6670^{* *}$ & $1603^{* *}$ & $62.7^{* *}$ & 0.009 \\
\hline & Error (28 df) & 2.50 & 19.65 & 867 & 0.00 & 5555 & 1266 & 59.6 & 0.007 \\
\hline \multicolumn{2}{|l|}{ Mean } & 58 & 79 & 275 & 1.00 & 204 & 105 & 17.26 & 0.18 \\
\hline \multicolumn{2}{|l|}{ Range } & $50-65$ & $69-90$ & $188-338$ & $1-1$ & $105-328$ & $58-178$ & $6.00-29.09$ & $0.06-0.38$ \\
\hline \multicolumn{2}{|c|}{ Phenotypic variance } & 17.50 & 48.16 & 2237 & 0.00 & 6112 & 1435 & 61.14 & 0.008 \\
\hline \multicolumn{2}{|c|}{ Genotypic variance } & 15.00 & 28.51 & 1371 & 0.00 & 558 & 169 & 1.58 & 0.001 \\
\hline \multicolumn{2}{|c|}{ Environment variance } & 2.50 & 19.65 & 866 & 0.00 & 5555 & 1266 & 59.56 & 0.007 \\
\hline \multicolumn{2}{|l|}{$\mathrm{PCV} \%$} & 7.19 & 8.79 & 17.20 & 0.00 & 38.37 & 36.31 & 45.32 & 49.06 \\
\hline \multicolumn{2}{|l|}{ GCV \% } & 6.66 & 6.76 & 13.46 & 0.00 & 11.59 & 12.45 & 7.29 & 15.53 \\
\hline \multicolumn{2}{|c|}{ Heritability \% } & 85.70 & 59.20 & 61.30 & 0.00 & 9.10 & 11.80 & 2.60 & 10.00 \\
\hline \multicolumn{2}{|c|}{ GA $(\%$ mean $)$} & 12.70 & 10.71 & 21.70 & 0.00 & 7.21 & 8.80 & 2.41 & 10.12 \\
\hline \multicolumn{10}{|c|}{ Pooled over locations $\left(\mathrm{E}_{1} \times \mathrm{E}_{2}\right)$} \\
\hline & Replications (1 df) & 0.001 & 1.40 & $8.25^{* *}$ & 0.001 & $912^{* *}$ & 1.38 & $337^{* *}$ & 0.02 \\
\hline sum of & Hybrids (28 df) & $47.2^{* *}$ & $50.9^{* *}$ & $2419^{* *}$ & 0.23 & $3825^{* *}$ & $1166^{* *}$ & $45.23^{* *}$ & 0.007 \\
\hline & Error (28 df) & 8.50 & 5.22 & 245 & 0.11 & 1302 & 297 & 15.06 & 0.002 \\
\hline Mean & & 57 & 81 & 257 & 1.10 & 201 & 96 & 17.25 & 0.18 \\
\hline Range & & $48-66$ & $73-92$ & $181-308$ & $1-1.50$ & 121-299 & $58-158$ & $7.93-27.10$ & $0.07-0.30$ \\
\hline Phenotyl & ic variance & 27.83 & 28.08 & 1332 & 0.17 & 2564 & 732 & 30.15 & 0.005 \\
\hline Genotyp & variance & 19.33 & 22.87 & 1087 & 0.06 & 1262 & 435 & 15.09 & 0.003 \\
\hline Environı & ent variance & 8.50 & 5.22 & 245.5 & 0.11 & 1192 & 297 & 15.06 & 0.002 \\
\hline PCV \% & & 9.33 & 6.52 & 14.19 & 34.16 & 23.44 & 26.49 & 29.63 & 33.49 \\
\hline GCV \% & & 7.77 & 5.88 & 12.81 & 20.77 & 16.45 & 20.42 & 20.96 & 25.68 \\
\hline Heritabi & ty $\%$ & 69.50 & 81.40 & 81.60 & 37.00 & 49.20 & 59.40 & 50.10 & 58.80 \\
\hline $\mathrm{GA}(\% \mathrm{n}$ & ean) & 13.35 & 10.93 & 23.84 & 26.01 & 23.77 & 32.43 & 30.55 & 40.58 \\
\hline
\end{tabular}

DF: Days to $50 \%$ flowering; DM: Days to maturity; PH: Plant height; LS: Lodging score; GFYP: Green fodder yield plant ${ }^{1}$; DFYP: Dry fodder yield plant ${ }^{-1}$; GYP: Grain yield plant ${ }^{-1}$; HI: Harvest index; ${ }^{*},{ }^{* *} p=0.05$ and $p=0.01$ levels, respectively; $\mathrm{GCV}=$ Genotypic coefficient of variation; $\mathrm{PCV}=$ Phenotypic coefficient of variation; $\mathrm{GA}(\% \mathrm{mean})=\mathrm{Genetic}$ advance as per cent of mean 
ICMV 08111 recorded the minimum $(0.07 \%)$ harvest index, whereas, check DFMH- 88 depicted maximum $(0.30 \%)$ harvest index among hybrids under studied.

The traits viz., green fodder yield plant $^{-1}$, dry fodder yield plant $^{-1}$ and plant height recorded higher genotypic and phenotypic variation than the other characters studied. Wide range of phenotypic variability was observed for green fodder yield plant ${ }^{-1}$, dry fodder yield plant ${ }^{-1}$ and plant height, indicating the scope for genetic improvement in these characters through selection and other breeding methods. On the other hand, days to $50 \%$ flowering, days to maturity and grain yield plant ${ }^{-1}$ exhibited moderate range of phenotypic variability. Harvest index and lodging score showed low magnitude of phenotypic variability. The higher estimates of genotypic variance over environmental variance in all the characters studied except lodging score revealed that the variation among the crosses had a genetic basis. The estimates of phenotypic and genotypic variances were high for green fodder yield plant ${ }^{-1}(2564,1262)$, plant height $(1332,1087)$ and dry fodder yield plant ${ }^{-1}(732$, 435). The phenotypic and genotypic variances were moderate for days to $50 \%$ flowering $(27.83,19.33)$, days to maturity $(28.08,22.87)$ and grain yield plant ${ }^{-1}(30.15,15.09)$; while, it was low for lodging score $(0.17,0.06)$ and harvest index $(0.005,0.003)$. The results achieved in the present study are in akin with Bhagirath Ram et al. (2007); Kale et al. (2011); Kumar et al. (2014); Salih et al. (2014); Singh et al. (2014a); Singh et al. (2014b); Dhedhi et al. (2015); Dhedhi et al. (2016) in pearl millet.

The relative amount of variation expressed by different traits was judged through estimates of phenotypic and genotypic co-efficient of variation. Though the Phenotypic Coefficient of Variation (PCV) was greater than Genotypic Coefficient of Variation (GCV) for all the characters studied, the close resemblance between the corresponding estimates of PCV and GCV in all the characters except lodging score suggested that the environment had little role in the expression of these characters. The characters like harvest index $(33.49 \%$, $25.68 \%)$, lodging score $(34.16 \%, 20.77 \%)$, grain yield plant ${ }^{-1}$ $(29.63 \%, 20.96 \%)$, dry fodder yield plant ${ }^{-1}(26.49 \%, 20.42 \%)$ and green fodder yield plant ${ }^{-1}(23.44 \%, 16.45 \%)$ exhibited high to medium magnitude of PCV and GCV indicating the presence of wide genetic variability for these traits and chances for improvement of these characters are fairly high. Low values of PCV and GCV were observed for days to $50 \%$ flowering $(9.33 \%, 7.77 \%)$, days to maturity $(6.52 \%, 5.88 \%)$ and plant height $(14.19 \%, 12.81 \%)$. These results are in conformity with the report of Kale et al. (2011); Dapke et al. (2014); Singh et al. (2014b); Dhedhi et al. (2015); Harinarayan et al. (2015); Dhedhi et al. (2016) in pearl millet.

The effectiveness of selection for any character depends, not only the extent of genetic variability but also in the extent to which it will be transferred from one generation to the other generation, because, only heritable portion of variation is exploitable through selection. The heritability estimates was interpreted as low $(<30 \%)$, moderate $(30-50 \%)$, high $(50-70 \%)$ and very high $(>70 \%)$ as per classification of Hallauer and Miranda (1981). Broad sense heritability ranged from 37.00 (lodging score) to $81.60 \%$ (plant height). Very high heritability estimate was recorded for plant height $(81.60 \%)$ and days to maturity $(81.40 \%)$, while high heritability estimate was observed for days to $50 \%$ flowering $(69.50 \%)$, dry fodder yield plant ${ }^{-1}(59.40 \%)$, harvest index $(58.80 \%)$ and grain yield plant ${ }^{-1}(50.10 \%)$. The high heritability may be due to additive gene effects hence these traits are likely to respond to direct selection. This was in agreement with the findings of Bhagirath Ram et al. (2007); Lakshmana et al. (2009); Dapke et al. (2014); Kumar et al. (2014); Singh et al. (2014a); Dhedhi et al. (2015) and Dhedhi et al. (2016). Genotypic coefficient of variability along with heritability estimates provides a better picture for the amount of genetic gain expected to be obtained from phenotypic selection (Burton, 1952). It was interesting to note that high GCV was accompanied with high heritability estimates for harvest index $(25.68 \%, 58.80 \%)$, dry fodder yield plant $^{-1}(20.42 \%, 59.40 \%)$ and grain yield plant ${ }^{-1}(20.96 \%$, $50.10 \%$ ) in the present material which further revealed that selection could be more effective for the improvement of these traits. The estimates of genetic advance did not project the actual genetic gain that has been attained in relation to the per se performance which obviously is not uniform in different populations and even in the same population under different environments. Therefore, the expected genetic gain as per cent of mean was computed. Estimates of genetic advance as percentage of mean ranged from $10.93 \%$ (days to maturity) to $40.58 \%$ (harvest index). Heritability in coupled with genetic gain was more useful than the heritability values alone in the prediction of the resultant effect for selecting the best individual genotypes (Johnson et al., 1955). Genetic gain gives an indication of expected genetic progress for a particular trait under suitable selection pressure. In the present study, the characters plant height $(81.60 \%, 23.84 \%)$, harvest index $(58.80 \%, 40.58 \%)$, dry fodder yield plant ${ }^{-1}(59.40 \%$, $32.43 \%)$ and grain yield plant ${ }^{-1}(50.10 \%, 30.55 \%)$ exhibited high heritability coupled with high to moderate genetic advance expressed as percentage of mean. These indicated the predominance of additive gene action in governing the traits and their suitability of selection for further improvement among the genotypes studied. These results are in accordance with those of Bhagirath Ram et al. (2007); Vidyadhar et al. (2007); Bhoite et al. (2008); Vinodhara et al. (2013); Salih et al. (2014); Dhedhi et al. (2015); Harinarayan et al. (2015); Dhedhi et al. (2016) in pearl millet. In the present studied, high heritability coupled with low genetic advance as per cent of mean was recorded for days to maturity $(81.40 \%, 10.93 \%)$ 
and days to $50 \%$ flowering $(69.50 \%, 13.35 \%)$ which might be due to preponderance of non-additive gene effects. Hence, it could be suggested that improvement of these characters might be difficult through simple selection. From the study of GCV, PCV, heritability and genetic advance it is inferred that simple selection among crosses could bring about significant improvement in the green fodder yield and its component characters as the GCV, PCV, heritability and estimated genetic advance were high.

Correlation coefficient is a statistical measure, which denotes the degree and magnitude of association between any two casually related variables. This association is due to pleiotropic gene action or linkage or more likely both. In plant breeding correlation coefficient analysis measures the mutual relationship between two characters and it determines character association for improvement fodder yield and other characters. Since the association pattern among yield components help to select the superior genotypes from divergent population based on more than one interrelated characters. Thus, information on the degree and magnitude of association between characters is of prime important for the breeder to initiate any selection plan. In general the genotypic correlation was generally of higher magnitude than phenotypic correlation (Table 3), indicating that inherent association between various characters studied. Green fodder yield plant ${ }^{-1}$ exhibited significant positive association with dry fodder yield plant ${ }^{-1}(0.962,0.926)$ and days to maturity $(0.483,0.395)$ at both genotypic and phenotypic levels and days to $50 \%$ flowering $(0.612)$ and plant height $(0.490)$ at genotypic level only. Green fodder yield plant ${ }^{-1}$ depicted non-significant and positive correlation with grain yield plant $^{-1}(0.355,0.217)$ at both genotypic and phenotypic levels and with plant height $(0.279)$ and days to $50 \%$ flowering $(0.230)$ at phenotypic level only. Negative and significant association of green fodder yield plant $^{-1}$ was observed with harvest index $(-0.532,-0.495)$ at both genotypic and phenotypic levels. Non-significant and negative correlation of green fodder yield plant ${ }^{-1}$ was manifested with lodging score (-0.077, -0.044$)$ at both genotypic and phenotypic levels. Interestingly, the characters which exhibited positive correlation with green fodder yield plant ${ }^{-1}$ have also depicted positive association among themselves. In the present study, significant positive association was observed for days to $50 \%$ flowering with days to maturity $(0.915,0.727)$, plant height $(0.832,0.634)$ and dry fodder yield plant ${ }^{-1}(0.765,0.392)$; days to maturity with plant height $(0.907,0.731)$ and dry fodder yield plant ${ }^{-1}(0.671,0.508)$; and plant height with dry fodder yield plant $^{-1}(0.624,0.393)$ at both genotypic and phenotypic levels. The similar results obtained by Bhagirath Ram et al. (2007); Kale et al. (2011); Abuali et al. (2012); Dapke et al. (2014); Kumar et al. (2014); Singh et al. (2014a); Dhedhi et al. (2015); Dhedhi et al. (2016) in pearl millet.

\begin{tabular}{|c|c|c|c|c|c|c|c|c|c|}
\hline Character & & $\begin{array}{c}\text { Days } \\
\text { to } 50 \% \\
\text { flowering }\end{array}$ & $\begin{array}{l}\text { Days to } \\
\text { maturity }\end{array}$ & $\begin{array}{l}\text { Plant } \\
\text { height } \\
(\mathrm{cm})\end{array}$ & $\begin{array}{c}\text { Lodging } \\
\text { score } \\
(1-5)\end{array}$ & $\begin{array}{l}\text { Green fodder } \\
\text { yield plant }{ }^{-1} \\
\text { (g) }\end{array}$ & $\begin{array}{l}\text { Dry fod- } \\
\text { der yield } \\
\text { plant }^{-1}(\mathrm{~g})\end{array}$ & $\begin{array}{c}\text { Grain } \\
\text { yield } \\
\text { plant }^{-1}(\mathrm{~g})\end{array}$ & $\begin{array}{c}\text { Harvest } \\
\text { index } \\
(\%)\end{array}$ \\
\hline \multirow{2}{*}{$\begin{array}{l}\text { Days to } 50 \% \\
\text { flowering }\end{array}$} & $\mathrm{rg}$ & 1.000 & $0.915^{* *}$ & $0.832^{* *}$ & 0.298 & $0.612^{* *}$ & $0.765^{* *}$ & -0.009 & $-0.647^{* *}$ \\
\hline & $\mathrm{rp}$ & 1.000 & $0.727^{* *}$ & $0.634^{* *}$ & 0.110 & 0.230 & $0.392^{*}$ & 0.018 & -0.285 \\
\hline \multirow[t]{2}{*}{ Days to maturity } & $\mathrm{rg}$ & & 1.000 & $0.907^{* *}$ & 0.201 & $0.483^{* *}$ & $0.671^{* *}$ & -0.263 & $-0.738^{* *}$ \\
\hline & $\mathrm{rp}$ & & 1.000 & $0.731^{* *}$ & 0.127 & $0.395^{*}$ & $0.508^{* *}$ & -0.085 & $-0.465^{*}$ \\
\hline \multirow[t]{2}{*}{ Plant height $(\mathrm{cm})$} & $\mathrm{rg}$ & & & 1.000 & 0.305 & $0.490^{* *}$ & $0.624^{* *}$ & 0.072 & $-0.434^{*}$ \\
\hline & $\mathrm{rp}$ & & & 1.000 & 0.234 & 0.279 & $0.393^{*}$ & -0.049 & -0.327 \\
\hline \multirow{2}{*}{$\begin{array}{l}\text { Lodging score } \\
(1-5)\end{array}$} & rg & & & & 1.000 & -0.077 & -0.002 & 0.142 & 0.183 \\
\hline & $\mathrm{rp}$ & & & & 1.000 & -0.044 & -0.087 & -0.010 & 0.132 \\
\hline \multirow{2}{*}{$\begin{array}{l}\text { Green fodder yield } \\
\text { plant }^{-1}(\mathrm{~g})\end{array}$} & rg & & & & & 1.000 & $0.962^{* *}$ & 0.355 & $-0.532^{* *}$ \\
\hline & $\mathrm{rp}$ & & & & & 1.000 & $0.926^{* *}$ & 0.217 & $-0.495^{* *}$ \\
\hline \multirow{2}{*}{$\begin{array}{l}\text { Dry fodder yield } \\
\text { plant }^{-1}(\mathrm{~g})\end{array}$} & $\mathrm{rg}$ & & & & & & 1.000 & 0.106 & $-0.722^{* *}$ \\
\hline & $\mathrm{rp}$ & & & & & & 1.000 & 0.061 & $-0.663^{* *}$ \\
\hline \multirow{2}{*}{$\begin{array}{l}\text { Grain yield } \\
\text { plant }^{-1}(\mathrm{~g})\end{array}$} & $\mathrm{rg}$ & & & & & & & 1.000 & $0.583^{* *}$ \\
\hline & $\mathrm{rp}$ & & & & & & & 1.000 & $0.615^{* *}$ \\
\hline \multirow{2}{*}{$\begin{array}{l}\text { Harvest index } \\
(\%)\end{array}$} & $\mathrm{rg}$ & & & & & & & & 1.000 \\
\hline & $\mathrm{rp}$ & & & & & & & & 1.000 \\
\hline
\end{tabular}




\section{Conclusion}

There is adequate genetic variability present in the material studied. In broad sense heritability, GCV, PCV, genetic gain and correlation among traits found that the selection for dry fodder yield plant ${ }^{-1}$, plant height, grain yield plant ${ }^{-1}$, harvest index, days to $50 \%$ flowering and days to maturity would be more effective traits in boosting green fodder yield performance of forage pearl millet hybrids.

\section{Acknowledgement}

Authors would like to thank International Crop Research Institute for the Semi Arid Tropics (ICRISAT), Patancheru, Hyderabad, providing seed materials for conducting field experiments.

\section{References}

Abuali, A.I., Abdelmulla, A.A., Idris, A.E., 2012. Character association and path analysis in pearl millet (Pennisetum glaucum L.). American Journal Experimental Agriculture 2(3), 370-381.

Bhagirath, R., Sharma, K.C., Sastry, E.V.D., 2007. Genetic variability, correlation and path analysis in fodder yield and related traits in pearl millet (Pennisetum glaucum L.). Agricultural Science Digest 27(1), 8-12.

Bhoite, K.D., Pardeshi, S.R., Mhaske, B.M., Wagh, M.P., 2008. Study of genetic variability in pearl millet (Pennisetum glaucum L.). Agricultural Science Digest 28, 111-117.

Burton, G.W., 1952. Quantitative inheritance in grasses. Proc. $6^{\text {th }}$ Int. Grassland Congress 1, 277-283.

Dapke, J.S., Shah, D.S., Pawar, G.N., Dhembre, V.M., Mithilesh Kumar, 2014. Genetic variability and character association over environment in pearl millet (Pennisetum glaucum L.) under dryland conditions of Gujarat. The Bioscan 9(2), 863-867.

Dhedhi, K.K., Ansodariya, V.V., Chaudhari, N.N., Sanghani, J.M., Sorathiya, J.S., 2015. Genetic variability and character association for fodder yield and its related traits in pearl millet over locations under rainfed conditions of Gujarat. International Journal of Forestry and Crop Improvement 6(2), 110-115.

Dhedhi, K.K., Ansodariya, V.V., Chaudhari, N.N., Sanghani, J.M., Sorathiya, J.S., 2016. Genetic variation among forage pearl millet genotypes for fodder yield and its component traits under rainfed conditions of Gujarat. The Bioscan 11(1), 45-48.

Falconer, D.S., 1964. 'Introduction to Quantitative Genetics' Oliver and Boyd, Edinburgh, 312-318.

Hallauer, A.R., Miranda, J.B., 1981. Quantitative Genetics in Maize Breeding. Lowa University Press, Ames, Lowa, USA.

Harinayan, B., Baudh, B., Kumar, S., Pandey, M.K., Kumar, D., Vishwakarma, D.N., 2015. Studies on genetic variability, for fodder yield and its contributing characters in bajra (Pennisetum glaucum L.). Agricultural Science Digest
35(1), 78-80.

Johnson, H.W., Robinson, H.F., Comstock, R.E., 1955. Genotypic and phenotypic correlation in soybeans and their implication in selection. Agronomy Journal 47, 477-483.

Kale, B.H., Jadeja, G.C., Patel, K.K., 2011. Genetic variability, correlation and path co-efficient in segregating generation of pearl millet (Pennisetum glaucum L.). International Journal of Agricultural Sciences 7(2), 373-377.

Kumar, Y., Lamba, R.A.S., Yadav, H.P., Kumar, R., Dev, V., 2014. Studies on variability and character association under rainfed conditions in pearl millet (Pennisetum glaucum L.) hybrids. Forage Research 39(4), 175-178.

Lakshmana, D., Biradar, B.D., Jolly, R.B., 2009. Variability studies in pearl millet germplasm lines (Pennisetum glaucum L.). Research on Crops 10(3), 687-689.

Lush, J.L., 1940. Intra-sire correlation and regression of offspring on dam as a method of estimating heritability of characters. In: Proceedings of American Society for Animal Production 33, 293-301.

Panse, W.G., Sukhatme, P.V., 1978. Statistical Methods for Agriculture Workers, $3^{\text {rd }}$ Rev. Ed., ICAR, New Delhi.

Salih, A.I.S., Mohamed, I.I., Elgailani, A., Khalid, A.O., Adam, M.A., 2014. Genetic variation among pearl millet genotypes for yield and its components in semi-arid zone Sudan. International Journal of Agricultural Crop Science 7(11), 822-826.

Shashikala, T., Rai, K.N., Balaji Naik, R., Shanti, M., Chandrika, V., Loka Reddy, K., 2013. Fodder potential of multicut pearl millet genotypes during summer season. International Journal of Bioresource and Stress Management 4(4), 628-630.

Singh, B., Upadhyay, P.K., Sharma, K.C., 2014a. Genetic variability, correlation and path analysis in pearl millet (Pennisetum glaucum L.). Indian Research Journal of Genetics and Biotechnology 6(3), 491-500.

Singh, S., Yadav, Y.P., Yadav, H.P., Dev, V., Yadav, N., 2014b. Studies on genetic variability and trait association for grain yield and its components in pearl millet [(Pennisetum glaucum (L.) R. BR.]. Forage Research 40(2), 91-94.

Snedecor, G.W., 1961. Statistical methods. Iowa State College Press, Ames, Lowa USA.

Vidyadhar, B., Pooran, C., Swanalatha, Devi, I., Vijaya, S.R.M., Ramachandraiah, D., 2007. Genetic variability and character association in pearl millet (Pennisetum glaucum L.) and their implications in selection. Indian Journal of Agricultural Research 41(2), 150-153.

Vinodhana Kumari, N., Sumathi, P., Sathya, M., 2013. Genetic variability and inter-relationship among morphoeconomic traits of pearl millet (Pennisetum glaucum L.) and their implications in selection. International Journal of plant, Animal and Environment Science 3(2), 145-149. 